\begin{tabular}{|c|c|c|}
\hline $\begin{array}{l}\text { PUCRS } \\
\text { PUCR }\end{array}$ & $\begin{array}{l}\text { ESCOLA DE } \\
\text { HUMANIDADES }\end{array}$ & $\begin{array}{l}\text { Revista Digital do Programa de Pós-Graduação em Letras da PUCRS } \\
\text { Letrônica, Porto Alegre, v. 13, n. 1, p. 1-10, jan.-mar. } 2020 \\
\text { e-ISSN: } 1984-4301\end{array}$ \\
\hline de) $\mathrm{http}: / / \mathrm{dx}$ & $\mathrm{rg} / 10.15448 / 1984-4301.2020 .1 .35147$ & \\
\hline
\end{tabular}

\title{
O(s) lugar(es) de Meus desacontecimentos, de Eliane Brum, na diversificada paleta da autoficção
}

\author{
The place(s) of Eliane Brum's Meus desacontecimentos in the diverse palette of autofiction \\ Lugar(es) de Meus desacontecimentos, de Eliane Brum, en la diversa gama de la autoficción
}

\author{
Jeferson de Moraes \\ Jacques $^{1}$ \\ orcid.org/0000-0003-0160-9494 \\ jeferson.jacques@edu.pucrs.br
}

Recebido em: 30 jul. 2019

Aprovado em: 7 nov. 2019

Publicado em: 7 abr. 2020.
Resumo: A escrita sobre si, popularizada a partir do século XVIII, podia ser categorizada por caracteristicas comuns a todos os textos desse escopo. Porém, devido à criatividade dos autores, com o tempo passou por diversas mudanças, tornando-se tão diversificada a ponto de não caber dentro de uma classificação fixa. Elementos ficcionais fizeram-na aproximar-se mais do romance do que da autobiografia: daí o surgimento do termo "autoficção", popularizado por Serge Doubrovsky em 1977, e toda a consequente discussão entre os teóricos sobre a dificuldade de caracterizar esse diferente modo de escrita de si. O presente artigo, após uma breve revisão do termo autoficção, visa a analisar o livro Meus desacontecimentos, de Eliane Brum, quanto ao tipo de recepção predominante que deseja para si, se enquanto factual ou fictício; e verificar em qual posição a obra se encontra no espectro dos conceitos para a autoficção publicados nas últimas décadas.

Palavras-chave: Autoficção. Meus desacontecimentos. Eliane Brum.

\begin{abstract}
The self-narrative itself, popularized from the eighteenth century, could be categorized by characteristics common to all texts within this scope. However, due to the creativity of the authors, over time it has undergone several changes, becoming so diverse that it does not fit within a rigid classification. Fictional elements brought her closer to the novel than to the autobiography: thus came the term 'autofiction', popularized by Serge Doubrovsky in 1977, and all the consequent discussion among theorists about the difficulty of characterizing this different self-narrative mode. This article, after a brief review of the term autofiction, aims to analyze Eliane Brum's book Meus desacontecimentos: the type of predominant reception this book want for itself, whether as factual or fictitious; and to verify where the book is in the spectrum of concepts for autofiction published in the last decades.
\end{abstract}

Keywords: Autofiction. Meus desacontecimentos. Eliane Brum.

Resumen: La narrativa del yo, popularizada a partir del siglo XVIII, podía ser categorizada por caracteristicas comunes a todos los textos de ese ámbito. Sin embargo, a causa de la creatividad de los autores, con el paso del tiempo, ha experimentado muchos cambios, razón por la cual ha llegado a ser tan diversa a punto de no ajustarse en una clasificación fija. Elementos ficcionales la han hecho acercarse más a la novela que a la autobiografía: desde ahi surge el término "autoficción", popularizado por Serge Doubrovsky en 1977, y todo el debate entre los teóricos sobre la dificultad de caracterizar ese diferente modo de narrativa del yo. El presente artículo, tras una breve revisión acerca del término autofifcción, tiene el objetivo de analizar el libro Meus desacontecimentos, de Eliane Brum, en cuanto al tipo de recepción predominante que desea para sí misma, fáctico o ficticio; y averiguar que posición ocupa la obra en el espectro de los conceptos de la autoficción publicados en las últimas décadas.

Palabras clave: Autoficción. Meus desacontecimentos. Eliane Brum. 


\section{Introdução}

Em 1977, houve a popularização do termo "autoficção" pelo escritor e critico francês Serge Doubrovsky, na ocasião do lançamento de seu livro Fils, na quarta capa, como um sinalizador de como a obra deveria ser recepcionada. 0 desejo do autor era que o seu livro tivesse as duas recepções possiveis: que ele fosse lido como um romance, contudo, sem desconsiderar seu lado factual, configurando uma espécie de pacto duplo. O próprio Doubrovsky, em seu artigo o último $e u^{2}$, assume que tal prática de escrita já existia, e afirma que sequer fora o criador da palavra, mas do possivel conceito ao qual ela se remete, que seria, de acordo com ele, uma espécie de "ficção, de fatos e acontecimentos estritamente reais" (2014, p. 120). Inevitavelmente, tal definição motivou a manifestação de outros autores, que publicaram trabalhos a respeito, de modo que alguns a desprezaram, outros encontraram nela diversas contradições, e outros ainda a ampliaram. Tal debate, ainda aberto, não possibilita que o termo autoficção possa ter características marcadoras de modo definitivo, o que precisa ser levado em consideração em qualquer tentativa de classificar textos de natureza da escrita sobre si publicados na atualidade. O presente texto, após uma breve revisão cronológica dos pressupostos de diferentes autores em relação ao termo, apresentará uma localização aproximada da obra Meus desacontecimentos, de Eliane Brum, dentro do amplo espectro de definições do termo autoficção.

\section{Jean-Louis Jeannelle e a cronologia do debate sobre a autoficção}

A cronologia de tal debate pós-Doubrovsky foi resumida por Jean-Louis Jeannelle, em seu ensaio $A$ quantas anda a reflexão sobre a autoficção?3: em 1989, Vincent Colonna, orientado por Gerard Genette, defendeu uma tese chamada L'autofiction. Essai sur la fictionalisation de soi em littérature, que permaneceu inédita até 2004, na qual amplia a definição de Doubrovsky. Jeannelle discorre sobre os critérios de Colonna:

[...] Escolheu aplicar o termo "autoficção" ao conjunto dos procedimentos de ficcionalização de si. De modo que a autenticidade dos fatos deixou de ser vista como condição de possibilidade: foi, ao contrário, a exploração do imaginário que passou a ser valorizada, sendo que o único critério de identificação aceito é o fato de que o escritor tome a si próprio como personagem de sua própria história e recorra a primeira pessoa ou até mesmo se designe de maneira mais indireta - com a condição, é claro, de que a identificação permaneça sempre óbvia aos olhos do leitor (2014, p. 133).

Quatro anos depois, Philipe Lejeune publicou um artigo chamado "Autoficção \& Cia.: peça em cinco atos"4, no qual estabelece um breve histórico da autoficção em forma de cinco atos, emulando uma narrativa teatral. Nele, Lejeune fala sobre as mudanças de Vincent Colonna em relação ao que fora inicialmente proposto por Doubrovsky:

\begin{abstract}
Uma autoficção é uma obra literária através da qual um escritor inventa para si uma personalidade e uma existência, embora conservando sua identidade real (seu nome verdadeiro). Embora intuitiva, esta definição possibilita desenhar os contornos de uma extensa classe, de um rico conjunto de textos: uma região literária parece dessa forma emergir do limbo da literatura (LEJEUNE, 2014, p. 26).
\end{abstract}

Tais redefinições e ampliações do conceito de autoficção não foram aceitas por determinados autores. O orientador da tese de Colonna, Gerard Genette, em seu artigo "Fiction e diction", publicado dois anos após a defesa de seu orientando, dividia os escritos estéticos em dois tipos: literariedade constitutiva e literariedade condicional; e dois modos principais: ficção e dicção. Para ele, a única forma de as narrativas factuais serem recebidas como literárias era a atenção estética do leitor. enquanto as narrativas ficcionais já possuiriam isso por direito (JEANNELLE, 2014, p. 133-134). Assim, Marie Darriusseq, em 1991, em sua tese, que tinha

\footnotetext{
2 Título original: Mon dernier moi - Tradução de Jovita Maria Gerhein Noronha e Maria Inês Coimbra Guedes. In: NORONHA, Jovita Maria Gerheim (org.). Ensaios sobre a autoficção. Belo Horizonte, UFMG, 2014.

3 Título original: Oú on em est la réflexion sur l'autofiction? - Tradução de Jovita Maria Gerhein Noronha e Maria Inês Coimbra Guedes. In NORONHA, Jovita Maria Gerheim (org.). Ensaios sobre a autoficção. Belo Horizonte, UFMG, 2014.

4 Título original: Autofictions \& Cie. Pièce em cinq actes - Tradução de Jovita Maria Gerhein Noronha e Maria Inês Coimbra Guedes. In: NORONHA, Jovita Maria Gerheim (org.). Ensaios sobre a autoficção. Belo Horizonte, UFMG, 2014.
} 
a intenção de "normalizar o estatuto ainda frágil da autoficção" (JEANNELLE, 2014, p. 134), apontava a conclusão de que a autoficção, ao requerer os dois pactos de leitura, factual e ficcional, entraria no "campo dos escritos constitutivamente literários" e, enquanto gênero, "no discurso acadêmico" (JEANNELLE, 2014, p. 134), o que acabou por motivar mais publicações dentro das noções de regulamentação da autoficção.

Em 2001, Philippe Forest propôs uma mudança na perspectiva sob a qual a autoficção estivera sendo estudada. Ele acreditava que o estudo da autoficção não deveria ser feito em função do modelo autobiográfico, mas do romanesco (JEANNELLE, 2014, p. 137). Para Forest, era clara a ideia de que qualquer narrativa de si fosse uma ficção, visto que, para narrar a própria história, o autor necessita transformar-se em um personagem, o que, naturalmente, aproximaria a autoficção do "romance do eu" (JEANNELLE, 2014, p. 137).

Em 2004, Vincent Colonna finalmente publica a sua referida tese, defendida em 1989. Nesta ocasião, o autor escreve um livro chamado Autofiction \& autres mythomanies litteraires, onde revisa a sua produção anterior e distancia um pouco mais os seus pressupostos anteriores das ideias de Doubrovsky. Para ele, a autoficção proposta por Doubrovsky era "apenas uma das manifestações da autoficção", no caso, a "autoficção biográfica", na qual, segundo atesta em teoria a "identidade nominal entre autor, narrador e personagem", porém com trabalho de estilo "de natureza romanesca" (JEANNELLE, 2014, p. 132).

Para diferenciar esse modelo de outros tipos de autoficção, Colonna criou o termo "autofabulação", dividindo-o em: a) autoficção fantástica, onde o escritor inventa para si uma vida; b) autoficção especular, onde o autor "se torna um dos personagens de sua narrativa fictícia"; e c) autoficção intrusiva (autoral), onde o narrador se manifesta "sem participar da intriga como personagem" (NORONHA, 2014, p. 39).

A partir dos materiais sobre autoficção publicados durante a década de 1990 até a publicação da tese de Colonna, em 2004. é notável como a validade referencial da autobiografia perdeu ênfase em virtude de suas cada vez maiores marcas de ficcionalização, e foi justamente esta característica que provocou o duelo de forças entre os teóricos. A próxima mudança de rumos nesse debate ocorreu no mesmo ano, 2004, com a publicação de Est-il je?, de Philippe Gasparini. Para ele, a diferença entre autoficção e romance autobiográfico seria que, na primeira, a identidade do sujeito encenado é claramente fictícia, enquanto na segunda ela permaneceria ambígua. Isso the levou à conclusão de que a autoficção é "um tipo particular de romance", o que o aproxima das definições de Vincent Colonna e o distancia de Serge Doubrovsky, que, mesmo reivindicando o aspecto romanesco, ainda dava validade ao que é referencial (JEANNELLE, 2014, p. 140-141).

Enquanto alguns autores ampliam a discussão, apontam contradições e acrescentam problemas, com o passar dos anos não houve qualquer consenso dos teóricos sobre a natureza do termo autoficção.

\subsection{Quatro apontamentos importantes de Jeannelle}

Jean-Louis Jeannelle, considerando todas as contribuições de seus predecessores, e com a intenção de "assegurar que o conceito (de autoficção) mantenha toda sua força" (2014, p. 141), manifesta as suas contribuições em forma de quatro apontamentos fundamentais no estudo da autoficção:

a) Ambiguidade e hibridez: Lejeune considerava que não haveria indicações de pacto, autobiográfico ou romanesco, formando uma ambiguidade. Porém, a invenção da autoficção se baseia justamente na presença de indicios contraditórios, configurando uma caracteristica híbrida (JEANNELLE, 2014, p. 142), que seria algo merecedor de mais atenção nos estudos;

b) Definição da ficção: para uns, significa um "modo narrativo constituído de asserções simuladas (trata-se do ficcional); para outros é "pelo recurso ao imaginário" (fictício); para outros, ainda, significa tudo que não é referencial (trata-se do falso)". Há, ainda, o perigo da extensão incontrolada do conceito de 
ficção (JEANNELLE, 2014, p. 145-148), o que traz problemas para as análises.

c) História literária e denominações genéricas: refere-se ao limite a ser fixado. Há dificuldade em reduzir a autoficção ao modelo da literatura contemporânea, bem como em definir características comuns tendo como base a história literária e a poética dos gêneros. Daí a resistência de alguns autores em aceitar a autoficção como um gênero (JEANNELLE, 2014, p. 151-152);

d) A imbricação das instâncias do discurso: refere-se à "falta de rigor conceitual", resultante das distintas lógicas em que operam "a teoria acadêmica", "os paratextos autorais" e a "crítica mundana" (JEANNELLE, 2014, p. 154).

Para Jeannelle (2014), é necessário abrir outras vias de exploração, e uma delas seria a critica genética. Tal afirmação o autor fundamenta com o argumento de que o conceito de autoficção proposto por Doubrovsky não surgiu na quarta capa de Fils, mas pelas características presentes no caminho de escrita percorrido pelo próprio autor na escrita, daí a importância da genética para os estudos futuros.

\section{2 posicionamento de Doubrovsky no longo debate}

Serge Doubrovsky, na ocasião da publicação de seu livro Fils, valeu-se do termo autoficção para sinalizar ao leitor a dupla recepção que almejava: a de um relato factual e um de texto romanesco. Philippe Gasparini, em seu artigo "Autoficção é o nome de quê?"5, diz que a palavra autoficção, em 1977, não designava um gênero, mas um texto: o próprio Fils (2014, p. 190-191). O autor relata que Doubrovsky, de 1978 a 1981, passara a desenvolver uma teoria sobre a autoficção a partir da explicação do próprio romance Fils, o que the renderia participações em colóquios. $O$ autor estaria compondo um conceito para uma nova modalidade de narrativa de si tendo como base o seu próprio texto, e ia reformulando a sua teoria a partir do trabalho como escritor. Contudo, depois de Fils, a obra que Doubrovsky classificaria como autoficção seria Une mère russe (Uma mãe russa), de Alain Bosquet. Porém, o livro não corresponde, necessariamente, à definição dowbrovskyana para a autoficção até aquele momento. Isso caracterizaria a autoficção, em 1984, como "uma certa ética fundada na dúvida sistemática", o que seria a "marca distintiva" do novo gênero (GASPARINI, 2014, p. 193). Após, Doubrovsky interrompeu a reflexão teórica e dedicou-se à sua produção literária, e limitou-se a "observar, e às vezes comentar, as interpretações" do conceito do qual diz ser o criador. Para ele, elas "variam e, por vezes, se contradizem", e lembra que a essência do gênero seria a definição que havia proposto: "ficção, de fatos e acontecimentos estritamente reais" (DOUBROVSKY, 2014, p. 120).

Doubrovsky mantém uma postura despreocupada em relação às diferentes reações de outros teóricos acerca da natureza da autoficção. Ele admite que esse termo, mesmo que "desprezado pelos puristas, correspondia a uma expectativa do público", foi necessário para "preencher uma lacuna ao lado das memórias, da autobiografia e das escritas intimas em geral" (DOUBROVSKY, 2014, p. 113). Quanto à autoficção constituir ou não um novo gênero, ele admite que seja uma questão ainda aberta, de modo que outros autores possam entendê-la em sentidos diferentes do proposto por ele. Doubrovsky reconhece a multiplicidade de olhares possiveis para a autoficção, ao que se refere como uma "variada paleta", que, além de útil, "constitui a riqueza" do termo (DOUBROVSKY, 2017, p. 113).

\section{0 livro Meus Desacontecimentos, de Eliane Brum}

Eliane Brum nasceu em Ijuí, Rio Grande do Sul, em 23 de maio de 1966. É repórter desde 1988, documentarista desde 2005, e ficcionista desde $2011^{6}$. Já ganhou mais de 40 prêmios

\footnotetext{
5 Título original: De quoi l'autofiction est-elle le nom? - Tradução de Jovita Maria Gerhein Noronha e Maria Inês Coimbra Guedes. In: NORONHA, Jovita Maria Gerheim (org.). Ensaios sobre a autoficção. Belo Horizonte, UFMG, 2014.

6 BRUM, Eliane. Trajetória. 201-. Homepage Eliane Brum desacontecimentos. Disponivel em: http://elianebrum.com/biografia. Acesso em: 30 jul. 2019
} 
nacionais e internacionais de reportagem, como Esso, Vladimir Herzog e Ayrton Senna. Trabalhou como repórter em vários jornais e revistas, tais como Zero Hora, onde permaneceu por 11 anos, e Revista Época, por 10 anos. Contabiliza seis livros, cinco de não ficção e um romance, e já participou de coletâneas de crônicas, contos e ensaios. Atualmente, Eliane possui colunas nos jornais El País e The Guardian, e sua carreira estende-se para além da escrita jornalística, pois ela é autora de livros e documentários.

Eliane foi vencedora do prêmio Açorianos como autora-revelação com seu livro Coluna Prestes - $O$ Avesso da Lenda (Artes e Ofícios, 1994). Nele, a autora refez, 70 anos depois, os 25 mil quilômetros da Coluna Prestes, e ouviu pessoas, de modo a reapresentar a história, desta vez sob o ponto de vista dos povoados e cidades por onde a tropa passou, no Brasil da República Velha. Tal mudança de perspectiva causou polêmicas na época do lançamento.?

Ainda no ramo da reportagem, publicou, em 2008, O olho da rua - Uma repórter em busca da literatura da vida real (Ed. Globo), no qual acompanha o trabalho de parteiras da floresta amazônica, e o testemunho dos últimos 115 dias de uma merendeira de escola em São Paulo, enquanto essa enfrenta um câncer.

Como romancista, publicou, em 2011, o seu romance de estreia, Uma duas (Leya), no qual as tensões de uma relação entre mãe e filha, em meio a uma doença da mãe, são o tema central. Em 2013. publicou A menina quebrada (Arquipélago Editorial), compilação de seus principais textos na coluna de opinião no site da revista Época.

Eliane atribui à escrita não só a profissão, mas algo que lhe dá sustentação em outros aspectos subjetivos da vida.

Hoje, ao lançar meus anzóis no lago nebuloso do passado, em busca de um mapa cujo único destino sou eu, percebo que escrever me salvou de tantas maneiras e também desta. Desde pequena tenho muita raiva - e quase nenhuma resignação. A reportagem me deu a chance de causar incêndios sem fogo e espernear contra as injustiças do mundo sem ir para a cadeia. Escrevo para não morrer, mas escrevo também para não matar (BRUM, 2017, p. 61).
Desde 2010 têm trabalhado como freelancer, e já acumula trabalhos filmicos. Em 2005, em parceria com Debora Diniz, escreveu e dirigiu Uma história Severina (Eliane Brum, Debora Diniz, 2005), no qual acompanha Severina Maria Leôncio Ferreira, internada em um hospital, em Recife, grávida de um feto sem cérebro. O dia em que Severina começa o seu processo de interrupção da gravidez coincide com a data em que os ministros do Supremo Tribunal Federal derrubaram a liminar que permitia que mulheres na condição dela antecipassem o parto quando o a gestação representasse risco à vida, o que é a temática problematizada no documentário.

Em 2010, em parceria com Paschoal Samora, roteirizou Gretchen Filme Estrada (Eliane Brum, Paschoal Samora, 2010), que retrata a última turnê da cantora e a sua candidatura à prefeitura da llha de Itamaracá (PE) pela coligação Partido Popular Socialista/Partido Verde (PPS/PV).

Em 2017, seguindo na linha de acompanhar algum momento da vida de uma personalidade, Eliane roteirizou Laerte-se (Lygia Barbosa da Silva, Eliane Brum, 2017), documentário original do serviço de streaming Netflix, sobre a cartunista Laerte Coutinho. A ênfase foi na vivência de Laerte em relação à sua transexualidade e como lidava com a possibilidade de intervenções em seu corpo como uma das etapas da transição de gênero.

Por fim, no documentário Eu+1 - Uma jornada de saúde mental na Amazônia (Eliane Brum, 2017), a autora acompanha por duas semanas um grupo de saúde mental chamado Clínica do Cuidado. Eliane possui, como principal característica de sua produção documental, uma ênfase a histórias reais que, de acordo com a autora, "jamais virariam notícia na pauta convencional do jornalismo", ao que ela chama de "desacontecimentos", bem representadas em seu livro $A$ vida que ninguém vê (Arquipélago Editorial, 2006):

\footnotetext{
Uma repórter em busca dos acontecimentos que não viram notícia e das pessoas que não são celebridades. Uma cronista à procura do extraordinário contido em cada vida anônima. Uma escritora que mergulha no cotidiano para provar que não existem vidas comuns. O mendigo que jamais pediu coisa alguma. O carre-
} 
gador de malas do aeroporto que nunca voou. O macaco que ao fugir da jaula foi ao bar beber uma cerveja. O álbum de fotografias atirado no lixo que começa com uma moça de família e termina com uma corista. O homem que comia vidro, mas só se machucava com a invisibilidade.

Essas fascinantes histórias da vida real fizeram sucesso no final dos anos 9o, quando as crônicas-reportagens eram publicadas na edição de sábado do jornal Zero Hora. Reunidas agora em livro, formam uma obra que emociona pela sensibilidade da prosa de Eliane Brum e pela agudeza do olhar que a repórter imprime aos seus personagens - todos eles tão extraordinariamente reais que parecem saídos de um livro de ficção. ${ }^{8}$

Em 2014, Eliane publicou Meus desacontecimentos - A história da minha vida com as palavras, no qual conta sua infância e sua estreita relação com a escrita, ao que atribui a própria existência.

\section{Estrutura e recursos utilizados pela autora}

O livro Meus desacontecimentos, de Eliane Brum, possui algumas marcas de ficcionalização, visto que a autora, ao falar sobre a sua infância e o lugar onde nasceu e cresceu, não deixa de criar uma personagem e um espaço. Tal recurso faz sentido no que diz respeito ao aspecto textual, a fim de criar a ambientação e a atmosfera almejada, porém, a autora não abandona o referencial. A estrutura de seu texto é como a de uma história de origem, onde a morte e a palavra "túmulo" estão presentes ao longo da genealogia da familia, sendo um eixo estruturador de comportamentos:

Minha avó descendia de uma família que falava com os mortos. Não como algo assustador ou sobrenatural, mas como parte da rotina da casa. Não havia fronteiras entre o mundo de cá e o de lá. Nem grandes revelações. Eram fantasmas bem domésticos. Os mortos seguiam na mesma toada de quando ainda eram vivos, arrastando pela casa seus chinelos de fumaça, assim como seus hábitos e arrependimentos. A diferença se dava no fato de que ninguém mais precisava gastar com seu sustento. $E$ recebiam ainda menos atenção do que quando ainda vivos (BRUM, 2017, p. 33-34).

Porém, a morte não ocupa um espaço apenas de diálogo cotidiano. Ela aparece de modo concreto, começando pela vivência da avó de Eliane:
Nela [avó], tudo era contido, até as carnes

A mãe dela morreu no parto, o que tornou minha avó culpada a priori por todas as desgraças que pudessem acontecer e aos parentes pela vida afora. E além. Andava pelo mundo em passinhos de feltro, pedindo desculpas por existir. Comedida em tudo, só esbanjava suspiros. Mas, quando acreditava que ninguém estava olhando, deixava escapar pela esquina dos olhos um desejo agoniado por um mundo mais largo. Morreu sem conseguir tornar-se o lado B de si mesma. (BRUM, 2017, p. 31).

A avó, então, foi criada por uma tia. O sentimento de culpa a fez deixar a escola para cuidá-la quando adoeceu, e nunca mais retomou os estudos.

Quando faltava um ano para conquistar o diploma
de magistério, a tia que a criava adoeceu. Minha
avó foi obrigada a deixar a escola para cuidar
de sua mãe postiça. Nunca mais voltaria. Não
sei se foi nesse ponto ou muito antes, ao ouvir
incontáveis vezes que a mãe morrera ao lhe dar
a luz, que acolheu um sentimento de fatalidade
que se agarraria a ela como uma segunda pele.
Eu a conheci já com seu ar de atriz de cinema
mudo, suspirando por uma vida que jamais
seria sua. Personagem trágica, a quem todas
as dores do mundo ainda seriam poucas, ela
estava sempre pronta a abraçar uma tristeza
nova. E como o sofrimento era mercadoria
valorizada naquele meio tão cristão, foi amea-
lhando pela vida aura de santidade. Ela, que se
adivinhava tão má, poderia ouvir pelo resto dos
dias como era boa, bastando para isso dar em
troca somente a alma (BRUM, 2017, p. 35 -36).

A culpa também recaiu sobre a sua mãe, devido ao falecimento de sua irmã ainda criança. Consequentemente, tal culpa foi herdada por Eliane, que nasceu e cresceu sob a presença dessa falecida irmã, cujo túmulo sempre era "carregada" a visitar.

Durante a infância minha mãe nos carregou, a mim e a meus irmãos, para o túmulo da filha que morreu. Minha irmã, a Maninha. E esse "carregou" tem mais sentidos do que o literal. Talvez minha mãe não pudesse acreditar e precisasse repetir, repetir, repetir. E a cada repetição, eu, a filha viva, sentia que a viva era a outra. E, mais morta do que viva, eu falhava em fazer renascer as partes ausentes da minha mãe. Só muito mais tarde eu descobriria que esta é a sina dos filhos que sobrevivem, chapinhando no lago escuro e sem fundo que é a dor sem consolo dos pais órfãos. Diante daquele túmulo, eu me esforçava para chorar. eu tentava sofrer pela outra, mas não conseguia. Poderia ser uma cena de cinema. A 
menina pequena de vestido rodado, com uma Chiquinha na cabeça, diante do túmulo de onde um anjo com asas a olhava. Mas, se alguém espiasse os meus pensamentos, saberia que sentia um alivio culpado pela morte da outra. Intuia que, se ela não tivesse morrido, eu não teria nascido. E mesmo torta, mesmo sendo um anjo de pernas tortas, eu queria viver. Mas não sabia como. Não ainda (BRUM, 2017, p. 12-13)

Passou a intuir que não teria nascido se não fosse por esse falecimento, e por ele sentir "um alívio culpado". Assim, a autora diz ter sido "rodeada por mulheres bondosas demais, e tristes, muito tristes", de modo que a sua percepção daquele contexto era de que "ser mulher era suportar a vida" (BRUM, 2017, p. 27).

Essa irmã, que era um túmulo no cemitério, um túmulo que ninguém da família conseguia fechar, muito menos eu, havia me roubado a casa, o sol, as roseiras, a luz. [...] Enquanto acreditei em Deus, e só acreditei até os onze anos, eu rezei antes de dormir por um milagre: acordar no dia seguinte com olhos azuis e cabelos loiros como os da minha irmã. Quando amanhecia, eu saltava da cama e corria a me olhar no espelho. E lá estava eu, marrom e imperfeita. [...] Maninha não tinha vivido apenas cinco meses, já que o tempo de um filho não se mede por dias, meses ou anos. Um filho é mundo sem tempo. [...] Minha irmã me deu uma bio, já que eu não nasceria se ela não tivesse morrido. Eu agora the dou uma grafia. Aqui consumamos nossa fusão, mas também a separação definitiva (BRUM, 2017, p. 19-21).

Eliane detestava o apartamento onde vivera até os cinco anos "por causa do escuro", pois lá "tudo era muito mortífero" (BRUM, 2017, p. 15). Diz que foi fundada pela percepção de que "o mundo era um túmulo" e a primeira memória é a escuridão do apartamento, "onde o sol pouco entrava" (2017, p. 18). A morte faz oposição ao nascimento, que se dá pela descoberta da leitura e da escrita, que é a ênfase de todo o livro, justificando, assim, o seu subtítulo: a história da minha vida com as palavras.

A autora, valendo-se de elementos específicos, faz referência ao Gênesis bíblico, e coloca a palavra escrita como a instância criadora maior, que dá origem à pessoa e à escritora: "sempre vou temer o retorno da escuridão, que para mim é o mundo sem palavras" (BRUM, 2017, p. 11). Ou:

Lembro-me que, quando tudo começou, era escuro. [...] Percebo que o escuro era uma au- sência. Uma ausência de palavras. Essa escuridão é minha pré-história. Eu antes da história, eu antes das palavras. Eu caos (BRUM, 2017, p. 9).

Seu nascimento pela descoberta das palavras modificou por completo o seu comportamento na infância:

\begin{abstract}
Ler - e depois escrever - foi a descoberta maior mediadora de tudo o que eu me tornaria. [...] Não queria brincar, não queria comer, não queria dormir. Eu queria ler. O lugar da realidade se inverteu. A paisagem dos livros era real. Eu me movia por ela e fazia o que esperavam que fizesse, mas não estava ali. Estava lá (BRUM, 2017, p. 80).
\end{abstract}

Tal nascimento é marcado por um momento específico, que é quando escreve uma poesia sobre o nascer do sol, aos nove anos, e o texto chegou às mãos de seu pai, que gostou. Era a primeira vez que um gesto dela chamava a atenção dele: finalmente, ela passara a existir para o pai. A partir dali, não pararia mais de escrever, escreveria "em qualquer lugar" (BRUM, 2017, p. 96).

A referência ao Gênesis também é feita pela presença de "jardins furiosos", sempre cultivados pelas mulheres de sua família, com exceção da mãe, que dizia ser "a única divorciada dos jardins" (BRUM, 2017, p. 47). Nestes espaços, elas vivem aquilo que, por razões de moralidade, precisam reprimir, tal como o fez sua tia:

[...] era lá que o coração daquelas mulheres pulsava em desatino, para onde escapavam de um corpo onde o desejo fora sepultado sob a lápide do casamento, das convenções e dos dias. Era lá que seu sexo pulsava, úmido e quente, devorando e sendo devorado [...]. Se no cotidiano ela se resignou aos canteiros ordenados da aparência, [...] seu quintal era a subversão da ordem. Lá ela plantou de tudo. [...] Deixava essa babel exuberante crescer e multiplicar-se segundo os humores de cada espécie. Enquanto entre as paredes da casa ela encarcerava suas grandes esperanças numa fachada de resignação, nos cantos sombrios de seu jardim o coração da minha tia batia com fúria (BRUM, 2017, p. 43-44).

Além da vivência corpórea referenciada pela presença dos "jardins furiosos", há, no próprio texto, uma maior proximidade com a vida orgânica: a maneira como a autora diz sentir as coisas, e a importância da palavra escrita nesta situação. 
Vivo tudo no corpo. Às vezes me perguntam o que aconteceria comigo se não existisse a palavra escrita. Eu respondo: teria me assassinado, consciente ou não de que estava me matando. [...] Se não pudesse rasgar o papel com a caneta, ainda que numa tela digital, eu possivelmente rasgaria ao meu corpo. E, em algum momento, o rasgaria demais (BRUM, 2017, p. 16).

Embora seja um detalhado relato de si, com um recorte maior recorte situado na infância e sua descoberta e nascimento pelas palavras, a autora utilizou-se de determinados recursos para fins de manutenção do envolvimento com o leitor e acrescentar dramaticidade: configurou a si mesma como um personagem que transita sobre a dualidade da vida e da morte, e a partir deste eixo mantém a atmosfera predominante de tristeza e introspecção, o que assegura a sua proximidade com a ficcionalização.

\section{A obra dentro do espectro da autoficção contemporânea}

A fim de localizar a obra Meus desacontecimentos na diversificada paleta da autoficção, faz-se necessário observar a quais pressupostos as características acima mais se relacionam. Como é sabido que a autoficção, em virtude de suas mais diversas formas de manifestação, não configura um gênero, o livro de Eliane Brum possui caracteristicas mencionadas por mais de um autor desde o início dos debates sobre o assunto. Embora partilhe da primeira premissa do próprio Doubrovsky (2014, p. 120), de que é uma "ficção, de fatos e acontecimentos estritamente reais", o texto de Eliane Brum encaixa-se, também, no segundo grupo da autofabulação criada por Vincent Colonna: autoficção biográfica (NORONHA, 2014, p. 39), pois o nome da autora não só é revelado como é detalhadamente explicado, eliminando qualquer dúvida quanto à associação da narradora com a personagem e a autora. Eliane é a heroína da história, e faz uso das mesmas informações reais para se autofabular.

Mas o melhor da minha vó eram as histórias urdidas com retalhos pinçados do território sem fronteiras do ontem. Ela era cheia de contos, e eu tinha ouvidos gulosos. Desde pequena, sou capaz de permanecer horas só escutando, sem a necessidade de falar de mim mesma. Pelas fábulas de familia minha avó resgatava um pretérito que nunca teve. Se não era possivel alcançar um amanhecer mais próximo de seus suspiros, ela compensava alinhavando seu antes com linhas bem coloridas, ás vezes, extravagantes. Minha avó sabia que, para algumas vidas, é mais fácil mudar o passado que o futuro (BRUM, 2017, p. 32).

Vemos não só um relato com percepção adulta dos referidos "desacontecimentos" da infância, mas a trajetória de uma personagem em idade infantil, com características introspectivas, às voltas com dúvidas sobre as razões de sua própria existência, enquanto se constitui por meio do convívio com as mulheres, tanto de sua familia como de fora dela e, posteriormente, pela leitura e todas as descobertas oriundas dessa prática contínua. Há, também, determinadas descrições de cenário, sempre dentro de uma coerência que a autora definiu desde o começo para o seu livro: o ambiente introspectivo permeado de subjetividades.

As mulheres da minha família gestavam jardins
furiosos. Havia algo de inquietante naque-
la selva para a qual me carregavam, e onde
eu me sentia mais viva do que em qualquer
outro lugar da infância. Ainda sem perceber
que era lá que o coração daquelas mulheres
pulsava em desatino, para onde escapavam
de um corpo em que o desejo fora sepultado
sob a lápide do casamento, das convenções
e dos dias. Era lá que seu sexo pulsava, úmi-
do e quente, devorando e sendo devorado,
enquanto elas ajeitavam os bobes no cabelo
(BRUM, 2017, p. 43).

A obra, embora apresente tais caracteristicas de autofabulação, não abandona o referencial, estando, assim, de acordo com a definição do próprio Philippe Lejeune sobre "pacto autobiográfico", que é "o compromisso que uma pessoa real assumia ao falar dela (própria) num espírito de verdade" (2013, p. 538), o que é explicado por Faedrich:

Uma concepção de contrato de leitura entre o autor e o leitor, [...] consiste nos principios de veracidade e de identidade entre Autor, Narrador e Personagem-protagonista $(A=N$ = P). O leitor toma o texto como a "verdade do individuo", marcando assim a diferença entre romance e autobiografia (ou memórias). No romance, o compromisso com a realidade é flou, diferentemente da autobiografia, em que o pacto de veracidade traz consequências legais 
para o autor (ele é responsável pelo que afirma, seja isso verdade ou não, ele terá de se justificar, pois está comprometido). Tal comprometimento é impensável no campo romanesco, em que o princípio de invenção e de não-identidade caracterizam o gênero (2014, p. 18).

Assim, embora exista uma narrativa esteticamente coesa dentro da atmosfera definida desde o início, algo que se situa entre o fúnebre e o mórbido, passando para o notável nascimento pelas palavras, o livro permanece, entretanto, relacionado diretamente com o referencial, visto que está de acordo com o pacto autobiográfico de Lejeune: a autora é a narradora e é a personagem $(A=N=P)$, e isso é claro para o leitor.

Torna-se pertinente trazer, novamente, as noções de Philippe Gasparini, para quem a autoficção é "um tipo particular de romance" (JEANNELLE, 2014, p. 141), e do próprio Lejeune: para ele, autoficção é uma obra "literária", e nela o escritor, embora preservando a sua identidade real e o seu nome verdadeiro, "inventa para si uma personalidade e uma existência". O autor assume essa definição como "intuitiva", mas reforça que, a partir dela, pode emergir "uma região literária" do "limbo da literatura" (2014, p. 26). É exatamente o que Eliane Brum faz com a sua escrita. A autora amplifica características psicológicas suas para uma finalidade definida e em momentos oportunos da sua trajetória desde o nascimento biológico, passando pelo nascimento pelas palavras até o fim da infância, textualmente criando um personagem, um espaço e uma ambientação. Porém, mesmo assim, ela convoca o leitor para um pacto de leitura focado no referencial em detrimento do ficcional, e isso assegura a concordância com o pacto autobiográfico de Lejeune $(A=N=P)$, o que traz uma ambiguidade entre realidade e ficção, característica da autoficção, na qual, de acordo com Faedrich (2014, p. 24 - 25), "o autor tem a liberdade para escrever, criar e recriar sobre um episódio ou uma experiência de sua vida, fazendo, assim, um pequeno recorte no tempo vivido", sendo assim "possivel misturar os gêneros, modificar a forma, ousar, experimentar".

Os "desacontecimentos" não são inventados, mas trazidos da memória e apenas organizados estrategicamente para o fim estético desejado, o que remete, novamente, a Doubrovsky:

No fundo, não há oposição entre autobiografia e romance. [...] Toda autobiografia participa do romance por duas razões. Uma formal: a autobiografia tal como se constituiu no século XVIII [...] toma de empréstimo a forma de narrativa em primeira pessoa encontrada nos romances da época. Mas há também outra razão que se relaciona com a natureza do empreendimento: Nenhuma memória é completa ou fiável. As lembranças são histórias que contamos a nós mesmos, nas quais se misturam, sabemos bem disso hoje, falsas lembranças encobridoras, lembranças truncadas ou remanejadas segundo as necessidades da causa. Toda biografia, qualquer que seja sua "sinceridade", seu desejo de "veracidade", comporta sua parte de ficção (2017, p. 121).

\section{Considerações finais}

Transitando basicamente entre Doubrovsky, Colonna, Gasparini e Lejeune, Meus desacontecimentos não possui apenas uma cor na diversificada paleta da autoficção, tampouco um tom, mas posiciona-se flutuante entre vários tons dentro de duas cores, no caso, várias características dentro de dois gêneros: autobiografia e romance. O livro almeja um pacto duplo que, de acordo com Faedrich (2014, p. 24), é "contraditório": embora não se verifique "com o autor o que é verdade e o que não é", também não entra totalmente no pacto romanesco/ficcional, pois não se quebra o pacto autobiográfico de Lejeune $(E=N=P)$. Assim, há uma ambiguidade que, de acordo com a autora (2014, p. 24), caracteriza a autoficção: a obra "não é autobiografia, nem romance", pois instaura-se no "entre-lugar" entre os dois. A escrita é feita a partir de um referencial trazido da memória da autora, porém, é feita por meio de um texto com marcas criativas que, por si só, atuam no envolvimento do leitor, e funcionam na medida em que ele, sem desconsiderar o factual, não depende exclusivamente dele para envolver-se com o texto. Tal caracteristica hibrida, de acordo com Jeanelle (2014, p. 142), deve ser considerada em análises, tanto suas quanto a outras obras com tais marcas. Eliane Brum, com o seu livro, 
junto a muitos outros títulos de diversos autores que narram a si mesmos sem reivindicar apenas um pacto de leitura, contribui para adicionar mais camadas no debate acerca dos possiveis conceitos aos quais remete a palavra autoficção.

\section{Referências}

BRUM, Eliane. Meus desacontecimentos: A história da minha vida com as palavras. Porto Alegre: Arquipélago Editorial, 2017.

BRUM, Eliane. Trajetória. 201- Homepage Eliane Brum desacontecimentos. Disponivel em: http:// elianebrum.com/biografia. Acesso em: 30 jul. 2019.

BRUM, Eliane; DINIZ, Debora. Uma história Severina. Brasil: [s. n.], 2005. Documentário. Português. (23 min)

BRUM, Eliane; SAMORA, Paschoal. Gretchen filme estrada. Documentário. Português. Brasil: [s. n.], 2010. (1h $30 \mathrm{~min}$ ).

BRUM, Eliane. Eu+1: Uma jornada de saúde mental na Amazônia. Brasil: [s. n.], 2017. Documentário. Português, (1h 42min).

BRUM, Eliane; SILVA, Lygia Barbosa da. Laerte-se. Brasil: [s. n.], 2017. Documentário. Português, (1h 41min).

DOUBROVSKY, Serge. O ultimo eu. Título original: Mon dernier moi - Tradução de Jovita Maria Gerhein Noronha e Maria Inês Coimbra Guedes. In: NORONHA, Jovita Maria Gerheim (org.). Ensaios sobre a autoficção. Belo Horizonte: UFMG, 2014. p. 111-125.

FAEDRICH, Anna Martins. Autoficções: do conceito teórico à prática na literatura brasileira contemporânea. 2014 $251 \mathrm{f}$. Tese (Doutorado em Letras) - Pontificia Universidade Católica do Rio Grande do Sul, Porto Alegre, 2014.

GASPARINI, Philippe. Autoficção é o nome de quê? Título original: De quoi l'autofiction est-elle le nom?. Tradução de Jovita Maria Gerhein Noronha e Maria Inês Coimbra Guedes. In: NORONHA, Jovita Maria Gerheim (org.). Ensaios sobre a autoficção. Belo Horizonte, UFMG, 2014. p. 181-221.

JEANNELLE, Jean-Louis. A quantas anda a reflexão sobre a autoficção? Título original: Où on em est la rèflexion sur l'autofiction? Tradução de Jovita Maria Gerhein Noronha e Maria Inês Coimbra Guedes. In: NORONHA, Jovita Maria Gerheim (org.). Ensaios sobre a autoficção. Belo Horizonte: UFMG, 2014. p. 127-162.

LEJEUNE, Philipe. Autoficção \& Cia.: peça em cinco atos. Título original: Autofictions \& Cie. Pièce em cinq actes. Tradução de Jovita Maria Gerhein Noronha e Maria Inês Coimbra Guedes. In: NORONHA, Jovita Maria Gerheim (org.). Ensaios sobre a autoficção. Belo Horizonte: UFMG, 2014. p. 21-37.

LEJEUNE, Philippe. Da autobiografia ao diário, da Universidade à associação: itinerários de uma pesquisa. Letras de Hoje, Porto Alegre, v. 48, n. 4, 2013.

NORONHA, Jovita Maria Gerheim (org.). Ensaios sobre a autoficção. Belo Horizonte: UFMG, 2014.

\section{Endereço para correspondência}

Jeferson de Moraes Jacques

Pontificia Universidade Católica do Rio Grande do Sul Av. Ipiranga, 6.681, Prédio 8, 4. ${ }^{\circ}$ andar, sala 403

Partenon, 90619-900

Porto Alegre, RS, Brasil

\section{Jeferson de Moraes Jacques}

Mestrando em Teoria Literária na Pontifícia Universidade Católica do Rio Grande do Sul. Professor de Literatura e Lingua Portuguesa na rede estadual, desenhista e instrutor de colorização. Pesquisador de narrativas gráficas e suas interfaces com literatura. O presente trabalho foi realizado com apoio da Coordenação de Aperfeiçoamento de Pessoal de Nivel Superior - Brasil (CAPES) - Código de Financiamento 001. 